For the implementation of development measures for missile artillery weapons, an adaptive plan can become an important element in the planning system, which provides timely regulation of the military-purpose system.

In order to plan activities for the development of missile and artillery weapons samples in the practice of the militarydefense system, it is necessary:

have a trained unit for adaptive planning with defined rights and responsibilities, with the task of solving specific problems;

direct their activities to specific organizations and institutions;

to take advantage of the strengths of the military system and the capabilities of the environment for the development of missile-artillery weapons samples;

to set specific terms for the implementation of activities (works);

have stable security;

to create a methodical device for adaptive planning, to train staff, to establish internal communication that would allow them to respond promptly to changes in the conditions of the situation, to exchange information and bring it to all relevant organizations and employees, coordinate their actions and have feedback.

Taking into account the requirements and approaches to adaptive planning of the military system, a typical structure of an adaptive plan for the development of missile-artillery weapons designs is based on the principles of adaptive planning (management). In general, the structure of the adaptive plan allows management in conjunction with the ability to take into account changes in the external and internal environment, which may cause the need for adjusting the plan already in the process of its implementation.

The identified requirements and the presented structure of an adaptive plan for the development of missile-artillery armament samples are typical (basic) ones, which in the final implementation for the developers of the adaptive plan need to be clarified and corrected.

Keywords: military system, adaptive planning, adaptive plan of measures, missile and artillery armament.

УДК 621.396 .96

I. Ryapolov, Y. Belevshchuk, H. Zubrytskyi, O. Bespalko

Ivan Kozhedub Kharkiv National Air Force University, Kharkiv

\title{
THE ESTIMATION OF THE CHARACTERISTICS OF SECONDARY RADIATION OF THE MODEL OF SU-27 SWING FIGHTER IN SHF, UHF AND VHF BAND
}

The relevance of researching the characteristics of radar scattering of modern air objects by means of mathematical modeling methods is substantiated in the article. The modern level of development of computer technology allows us to solve this problem and to implement rather complicated methods of mathematical modeling of secondary radiation of air objects with the necessary accuracy for use in practice. The analysis of existing methods for the estimation of secondary emissions of airborne objects is carried out, which allow to achieve the set goal - to obtain characteristics of radar scattering model of Su-27 swing fighter. The advantages in this case are methods based on integral representations of classical electrodynamics and their short-wave asymptotics. The model of the surface of Su-27 aircraft is developed and the basic calculation correlations are based on which the numerical modelling method was developed. The results of calculating the characteristics of radar scattering (effective scattering surface, "incoherent" effective surface of scattering, average and median values of the effective scattering surface) of Su-27 aircraft for different irradiation frequencies of the probing signal are given. The obtained results can be used at the stage of modernization and design of promising domestic radar systems to estimate the possibilities of various constructive variants of systems considered for the identification, support and recognition of air objects of this type. In addition, using the results obtained with the help of the developed method of mathematical modeling, will optimize the design of promising domestic aircraft in order to reduce their radar visibility. The developed method allows to carry out numerical modeling of radar characteristics of air objects of different types with given polarizations, spatial and temporal frequency parameters of probing signals in interests of solving a wide range of applied radar tasks.

Keywords: aerodynamic air object, secondary radiation, effective surface of scattering, method of mathematical modeling, radar characteristics 


\section{Introduction}

Problem statement. Army Aviation (Airborne Ground Forces) includes aeromobile equipment, which performs various tasks in the course of combat operations. The protection of such equipment and increasing its resistance to the radar impact of the enemy is an issue of the present day.

The availability of data about the characteristics of the secondary radiation of the aircraft makes it possible to solve several practical problems of radar. On the one hand, to carry out a complex of measures for the formation of a positional area of units providing intelligence and combat information of the unit and subdivision of anti-aircraft missile troops. On the other hand, it is possible to receive information that allows us to identify areas of the surface of the object that make a dominant contribution to the inverse scattering of the object as a whole. It will provide an opportunity to estimate the effectiveness of nonforeseeable measures to optimize the radar characteristics of both the entire object and its individual sections.

There are two most well-known ways of obtaining radar information on air objects: physical (physical) experiments and mathematical modeling of secondary radiation of airborne objects.

Each of the proposed methods involves certain difficulties. So, when carrying out natural (physical) experiments, huge colossal material, organizational and time costs are necessary. The main difficulties in mathematical modeling of secondary radiation of models of air objects are connected with the accuracy of the development of the model itself, the correctness of its mathematical description, and others.

The modern level of development of computing technology allows to implement rather complicated methods of mathematical modeling of secondary radiation of air objects with the necessary accuracy for use in practice.

Thus, the calculation of the scattering characteristics of modern airborne objects is an actual scientific task.

Analysis of literature. Obtaining the scattering characteristics of air objects was carried out on the basis of previously established high-frequency methods of calculation [1, 2], but their general disadvantage is the lack of a comprehensive accounting of the totality of dominant factors.

The method for calculating the effective reflective area (ERA) of an antenna system with a nose dielectric flow is proposed in [3-5]. The methods that allow to calculate the scattering characteristics of objects of complex geometric shape in a free space with a nonideally reflective surface are presented in [3-5].

The method which allows taking into account the reflection of an electromagnetic wave (EMW) between elements of a complex object is proposed in [6].
The methods [3-6] are based on the integral representations of classical electrodynamics (which can be obtained using the Lorentz lemma) and shortwave asymptotes and allow us to obtain the results of the scattering characteristics of air objects with sufficient accuracy for practical application.

The purpose of the article is to obtain radar characteristics (ERA, "incoherent" ERA, average and median values of ERA, distribution laws of the amplitude factor of the reflected signal) on the example of Su-27 swing fighter using the methods presented in [3-6].

\section{Main part}

$\mathrm{Su}-27$ is all-weather swing fighter (SF) of fourthgeneration (Fig. 1), designed to gain superiority in the air [7].

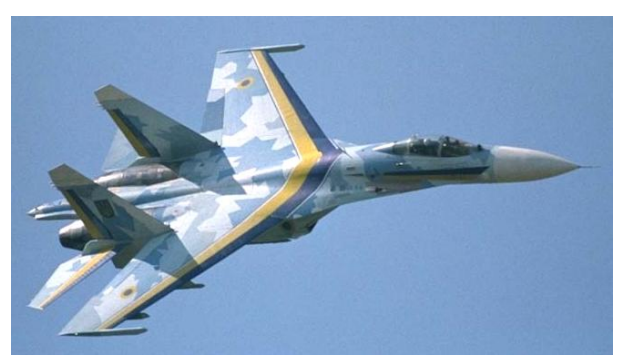

Fig. 1. Su-27 multirole fighter

For the first time, the aircraft was shown at the next air show in Le Bourget in 1989. The specialists were impressed by the promising design, ease of handling and the impressive aerodynamic qualities of this vehicle. A huge impression on the persons present was made by the acrobatic maneuver "cobra", when the aircraft suddenly throws its nose sharply, continuing to fly forward. At the same time, incidence angle increases, passes 90-degree mark and reaches 120 degrees, so the aircraft flies "tail forward".

This technique is not available to any other combat plane in the world. Specialists have indicated that dynamic braking can be used in air combat when targets are attacked from a disadvantage, for example, to launch missiles in the back hemisphere. High qualities of Su-27 are highlighted in many articles published by the Western press. The aircraft is among the best combat planes in the world. The tactical advantage of Su-27 over the modern F-15, F-16, F-18, Mirage-2000 and Rafal Western planes, which can not perform the acrobatic maneuver "cobra" was especially noticed. In fact, the combat plane, went beyond the boundary regimes of flight, which all Western constructors and air forces are dreaming of, was already in the hands of the Soviet Union [8].

1. Description of the modeling object and its surface model. In its design, Su-27 aircraft was designed in a normal aerodynamic scheme with a trapezoidal low midwing, two engines mounted under 
trapezoidal low midwing, two engines mounted under the carcass and two-axle spacers spaced along the outer sides of the tail beam with a vertical tail surfaces. The fuselage is a semimonoconal construction integrally conjugate with the wing and is technologically divided into the following main parts, such as the main part with the cowling and the canopy of the pilot, the middle part with the brake flap and the gear doors, the tail section [8-14].

The specific characteristics of $\mathrm{Su}-27$ are as follows: wingspan is $14.70 \mathrm{~m}$, length is $21.935 \mathrm{~m}$, height is $5.932 \mathrm{~m}$, mass is $16300 \ldots 30000 \mathrm{~kg}$, engine type is bypass turbojet with afterburner duct of $\mathrm{AL}-31 \mathrm{~F}$, maximum speed is $2500 \mathrm{~km} / \mathrm{h}$, mission radius

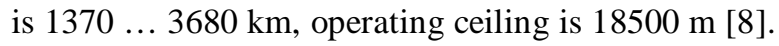

In accordance with the construction of $\mathrm{Su}-27$, a model of its surface was constructed for the calculation of radar characteristics (RCs) (in particular, ERA).

The surface model Su-27 SF is shown in Fig. 2

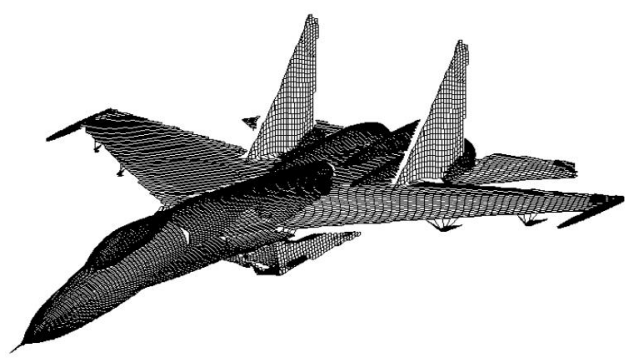

Fig. 2. The surface model Su-27 SF

The surface modeling was carried out in accordance with the methodology, which is given in [3$6]$. This methodology involves the partitioning of the surfaces, and the elements of the object are scattered into two groups: the smooth part of the surface and the edges of the local scattering areas, as well as the antenna system, which is located under the nosemounted dielectric radome. The smooth surface of the plane was approximated with the help of sections 60 of the three-axis ellipsoids. Surfaces were simulated using 42 straight local scattering brittle areas.

2. Basic calculation ratios. The main characteristic that defines the properties of the object reflects electromagnetic waves is ERA [3-6, 9]:

$$
\sigma=\lim _{R \rightarrow \infty} 4 \pi R^{2} \frac{\left|\overrightarrow{\mathrm{p}}^{\Pi p} \cdot \overrightarrow{\mathrm{E}}_{S}\right|^{2}}{\left|\overrightarrow{\mathrm{p}}^{0} \cdot \overrightarrow{\mathrm{E}}^{0}\right|^{2}},
$$

where $\mathrm{R}$ is the distance from the object to the observer point;

$\overrightarrow{\mathrm{p}}^{\Pi \mathrm{p}}, \overrightarrow{\mathrm{p}}^{0}$ is the polarization orts of the receiving and transmitting antennas, respectively;

$\overrightarrow{\mathrm{E}}_{\mathrm{S}}$ is complex amplitude of the field, scattered in the direction of the point of reception of the signal;
$\overrightarrow{\mathrm{E}}^{0}$ is complex amplitude of the field of flat monochromatic EMW, sounding object.

It is assumed that the sounding is carried out by a flat monochromatic EMW of a unit amplitude with an ort of polarization and a direction of propagation characterized by an orthosis that falls to the surface of an object located in free space (Fig. 2):

$$
\begin{gathered}
\overrightarrow{\mathrm{E}}^{0}(\overrightarrow{\mathrm{x}})=\overrightarrow{\mathrm{p}}^{0} \exp \left(\mathrm{jk}_{0}\left(\overrightarrow{\mathrm{R}}^{0} \cdot \overrightarrow{\mathrm{x}}\right)\right) \\
\overrightarrow{\mathrm{H}}^{0}(\overrightarrow{\mathrm{x}})=\sqrt{\frac{\varepsilon_{0}}{\mu_{0}}}\left(\overrightarrow{\mathrm{R}}^{0} \times \overrightarrow{\mathrm{p}}^{0}\right) \exp \left(\mathrm{jk}_{0}\left(\overrightarrow{\mathrm{R}}^{0} \cdot \overrightarrow{\mathrm{x}}\right)\right)
\end{gathered}
$$

where $\mathrm{k}_{0}$ is the wave number in the free space $\left(\mathrm{k}_{0}=2 \pi / \lambda, \quad \lambda\right.$ is the length of the incident monochromatic wave), $\varepsilon_{0}, \mu_{0}$ is the absolute dielectric and magnetic permeability of the vacuum, $\vec{x}$ is the radius vector of the point on the surface of the object. The field scattered by an object in a direction, by means of the Lorentz lemma, can be represented as [3-6]:

$$
\begin{aligned}
& \overrightarrow{\mathrm{p}}^{\Pi \mathrm{p}} \cdot \overrightarrow{\mathrm{E}}_{\mathrm{S}}=-\mathrm{jk} \mathrm{k}_{0} \frac{\exp \left(j \mathrm{k}_{0} \mathrm{R}\right)}{4 \pi \mathrm{R}} \\
& \cdot \int_{S}\left(\sqrt{\frac{\mu_{0}}{\varepsilon_{0}}}\left(\overrightarrow{\mathrm{p}} \cdot \overrightarrow{\mathrm{H}}^{\perp}\right)+\left(\overrightarrow{\mathrm{p}} \times \overrightarrow{\mathrm{r}}^{0}\right) \cdot \overrightarrow{\mathrm{E}}^{\perp}\right) \exp \left(-\mathrm{jk} \mathrm{k}_{0}\left(\overrightarrow{\mathrm{r}}^{0} \cdot \overrightarrow{\mathrm{x}}\right)\right) \mathrm{d} \mathrm{S},
\end{aligned}
$$

where $\quad \overrightarrow{\mathrm{E}}^{\perp}=\overrightarrow{\mathrm{n}} \times \overrightarrow{\mathrm{E}}, \quad \overrightarrow{\mathrm{H}}^{\perp}=\overrightarrow{\mathrm{n}} \times \overrightarrow{\mathrm{H}}, \quad(\overrightarrow{\mathrm{E}}, \overrightarrow{\mathrm{H}}) \quad$ is complete field; $\vec{n}$ is unitary vector of the external normal to the surface of the integration, covers this object.

The surface is selected so that it coincides with the surface of the object everywhere except the vicinity of the fractures, where it passes through the toroidal surface of a circular section that is "tense" to the break.

The surface can be represented as a sum $\mathrm{S}=\mathrm{S}_{1}+\mathrm{S}_{0}$, where $\mathrm{S}_{1}$ coincides with smooth sections of the surface, and $S_{0}$ is the collection of toroidal neighborhoods of the edges. Thus, the integral in (4) is the sum of integrals over the surfaces $S_{1}$ and $S_{0}$.

The field, scattered by the smooth part of the surface of the object in the direction, can be represented as part of the expression (4):

$$
\begin{gathered}
\overrightarrow{\mathrm{p}}^{\Pi \mathrm{p}} \cdot \overrightarrow{\mathrm{E}}_{\mathrm{S}_{1}}=-\mathrm{j \textrm {k } _ { 0 }} \frac{\exp \left(\mathrm{jk}_{0} \mathrm{R}\right)}{4 \pi \mathrm{R}} . \\
\cdot \int_{\mathrm{S}_{1}}\left(\sqrt{\frac{\mu_{0}}{\varepsilon_{0}}}\left(\overrightarrow{\mathrm{p}} \cdot \overrightarrow{\mathrm{H}}^{\perp}\right)+\left(\overrightarrow{\mathrm{p}} \times \overrightarrow{\mathrm{r}}^{0}\right) \cdot \overrightarrow{\mathrm{E}}^{\perp}\right) \exp \left(-\mathrm{jk}_{0}\left(\overrightarrow{\mathrm{r}}^{0} \cdot \overrightarrow{\mathrm{x}}\right)\right) \mathrm{dS} .
\end{gathered}
$$

The expression for the field scattered by the edgelocalized scattering regions can be represented as:

$$
\overrightarrow{\mathrm{p}}^{\Pi \mathrm{p}} \cdot \overrightarrow{\mathrm{E}}_{\mathrm{S}_{0}}=-\mathrm{jk} \mathrm{k}_{0} \sqrt{\frac{\mu_{0}}{\varepsilon_{0}}} \frac{\exp \left(j \mathrm{k}_{0} \mathrm{R}\right)}{4 \pi \mathrm{R}}\left(\overrightarrow{\mathrm{p}} \cdot \overrightarrow{\mathrm{F}}\left(\overrightarrow{\mathrm{r}}^{0}\right)\right),
$$




$$
\overrightarrow{\mathrm{F}}\left(\overrightarrow{\mathrm{r}}^{0}\right)=
$$

where $=\int_{\mathrm{S}_{0}}\left[\overrightarrow{\mathrm{H}}^{\perp}-\sqrt{\frac{\varepsilon_{0}}{\mu_{0}}}\left(\overrightarrow{\mathrm{E}}^{\perp} \times \overrightarrow{\mathrm{r}}^{0}\right)\right] \exp \left(-\mathrm{jk} \mathrm{k}_{0}\left(\overrightarrow{\mathrm{r}}^{0} \cdot \overrightarrow{\mathrm{x}}\right)\right) \mathrm{dS}$.

3. Radar characteristics of Su-27 SF model under different radiation frequencies (wavelengths). The calculation of the scattering characteristics of Su-27 SF was carried out with the following parameters:

- the angle of the sensing site is -3 degrees relative to the horizon plane (probing from the lower halfsphere)

- the step of changing the azimuth of the sensing is 0.02 degrees, the azimuth is counted in degrees from the nose angle ( 0 degrees - sounding in the nose, 180 degrees - sounding in the tail)

- polarization is horizontal.

The following EMWs are given: circular diagrams of ERA and "incoherent" ERA; the average and median values of instantaneous ERA for the main ranges of azimuth radiation (nose (0-45 degrees), side (45-135 degrees), tail (135-180 degrees)), as well as mean and median values of instantaneous ERA for twenty-degree ranges of azimuth radiation .

Under the median value of ERA in a particular sector of the angles of irradiation are understood to mean some random value of ERA, the probability of exceeding or not exceeding in the given sector of the angles is 0.5 .

Under "incoherent" ERO (IERO) is understood as the sum of EROs of individual parts of the surface, which does not take into account mutual phase taper.

The histograms of the amplitude factor of the reflected signal for different frequency of irradiation of the sounding signal are given.

All of the listed characteristics are given for the case of joint reception

3.1 RCs of $\mathrm{Su}-27 \mathrm{SF}$ model at an radiation frequency of $10 \mathrm{GHz}$ (wavelength is $3 \mathrm{~cm}$ )

The circular diagram of ERA of Su-27 SF model is shown in fig. 3.

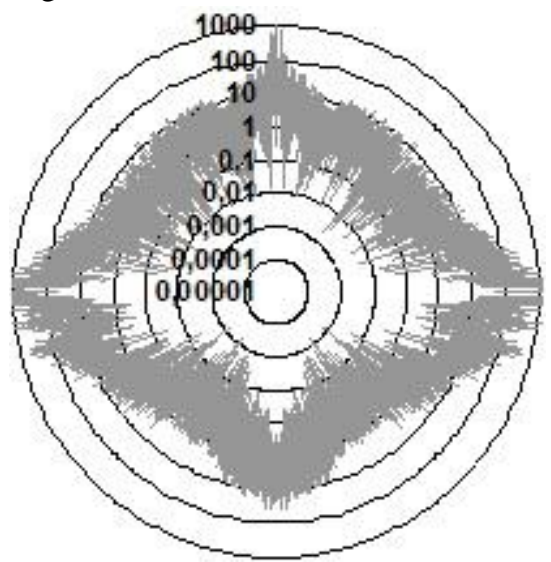

Fig. 3. The circular diagram of ERA of Su-27 SF model
The circular diagram of IERA of $\mathrm{Su}-27 \mathrm{SF}$ model is shown in fig. 4 .

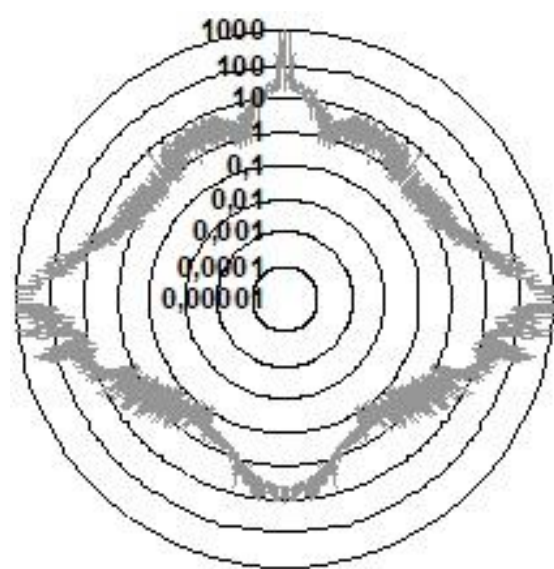

Fig. 4 The circular diagram of IERA of Su-27 SF model

The average value of ERA of Su-27 SF model is $83.04 \mathrm{~m}^{2}$. The circular median value of ERA (values of ERA used in calculations of aircraft detection range with a probability of 0.5 ) is $2.06 \mathrm{~m}^{2}$.

The average and median values of ERA for the main ranges of radiation azimuth (nose, side, tail) are shown in fig. 5 .

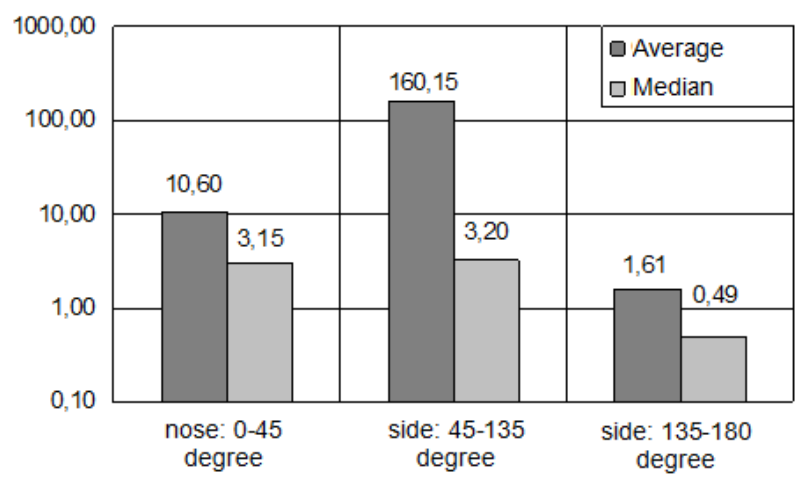

Fig. 5. The average and median values of ERA for the main ranges of radiation azimuth (nose, side, tail)

The averageve and median values of ERAs for ranges of 20 degrees are shown in fig 6.

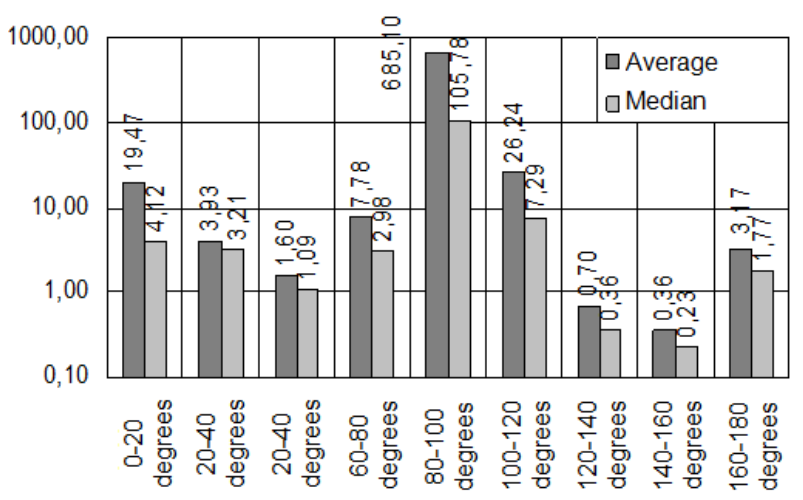

Fig. 6. The average and median values of ERA for twenty-degree ranges of radiation azimuth 
3.2 RCs of $\mathrm{Su}-27 \mathrm{SF}$ model at an radiation frequency of $1 \mathrm{GHz}$ (wavelength is $30 \mathrm{~cm}$ )

The circular diagram of ERA of Su-27 SF model is shown in fig. 7 .

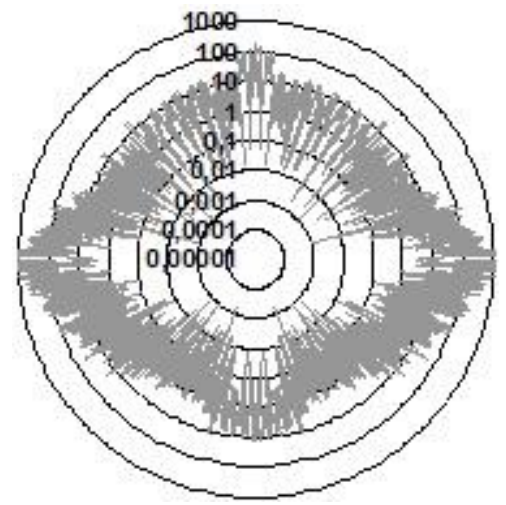

Fig. 7. The circular diagram of ERA of $\mathrm{Su}-27 \mathrm{SF}$ model

The circular diagram of IERA of Su-27 SF model is shown in fig. 8 .

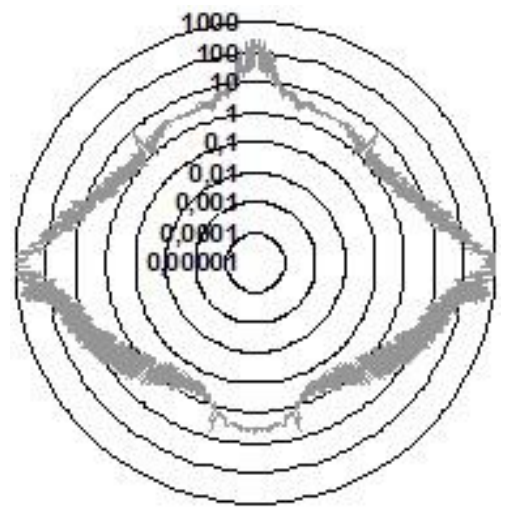

Fig. 8. The circular diagram of IERA of Su-27 SF model

The average value of ERA of Su-27 SF model is $58.92 \mathrm{~m}^{2}$; the circular median value of ERA is $2.51 \mathrm{~m}^{2}$.

The average and median values of ERA for the main ranges of radiation azimuth (nose, side, tail) are shown in fig. 9.

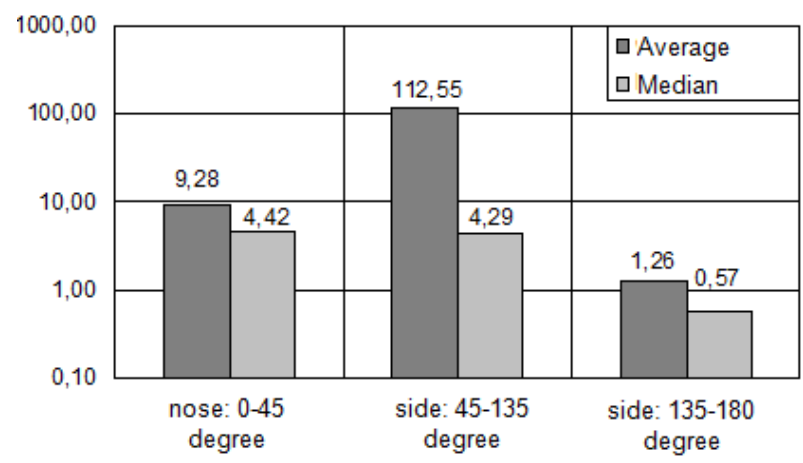

Fig. 9. The average and median values of ERA for the main ranges of radiation azimuth (nose, side, tail)
The average and median values of ERA for ranges of 20 degrees are shown in fig. 10.

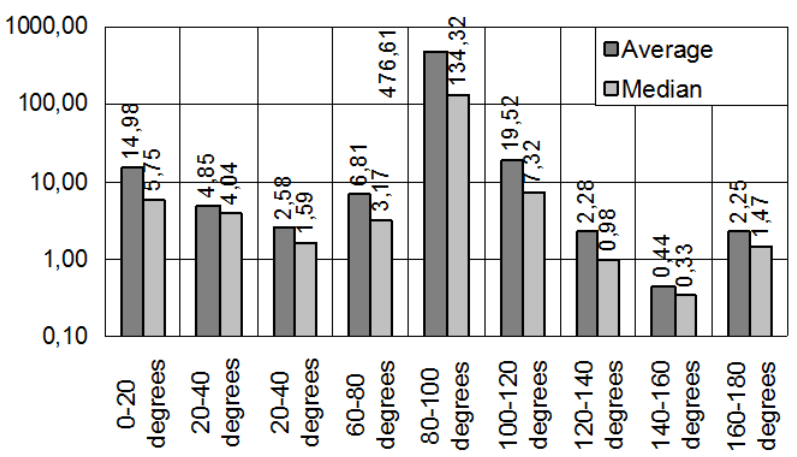

Fig. 10. The average and medium values of ERA for twenty-degree ranges of radiation azimuth

3.3 RCs of Su-27 SF model with a frequency of $166 \mathrm{MHz}$ (wavelength is $1.8 \mathrm{~m}$ )

The circular diagram of ERA of Su-27 SF model is shown in fig. 11.

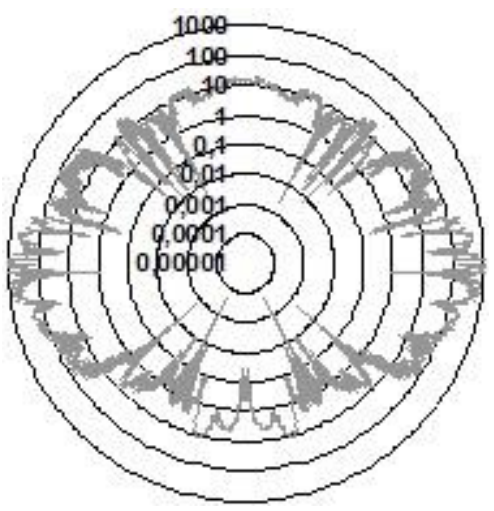

Fig. 11. The circular diagram of ERA of Su-27 SF model

The circular diagram of IERA of $\mathrm{Su}-27 \mathrm{SF}$ model is shown in fig. 12 .

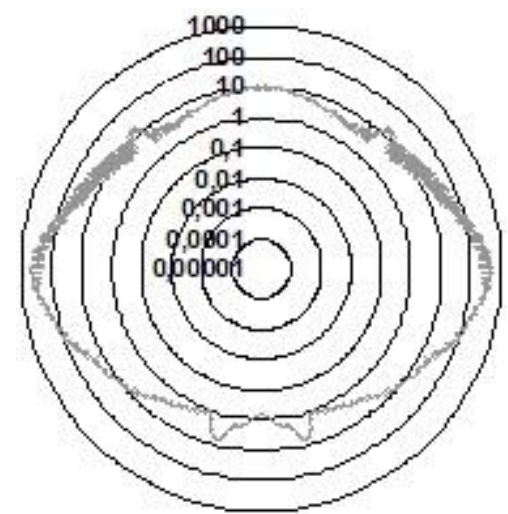

Fig. 12. The circular diagram of IERA of Su-27 SF model

The average value of ERA of Su-27 SF model is $70.02 \mathrm{~m}^{2}$; the circular median value of ERA is $9.45 \mathrm{~m}^{2}$. 
The average and median values of ERA for the main ranges of radiation azimuth (nose, side, tail) are shown in fig. 13.

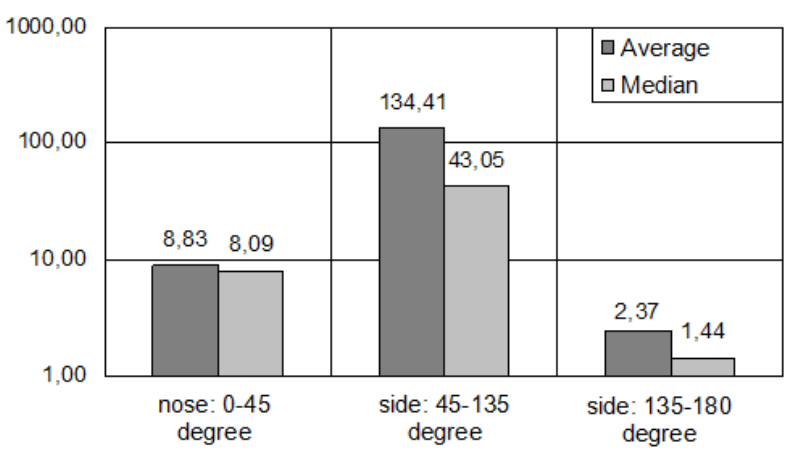

Fig. 13. The average and medium values of ERA for the main ranges of radiation azimuth (nose, side, tail)

The average and median values of ERA for the 20 degree ranges are shown in fig. 14.

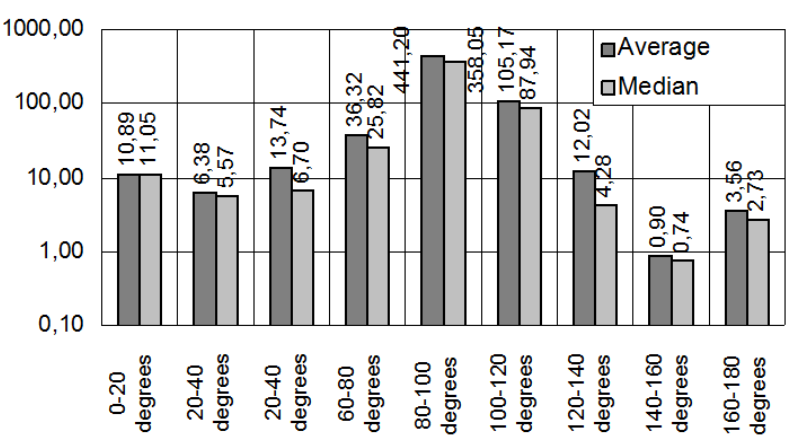

Fig. 14. The average and medium values of ERA for twenty-degree ranges of radiation azimuth

\section{Conclusions}

The analysis of the methods for calculating the characteristics of scattering of air objects was carried out and the necessity of obtaining a priori information about their radar characteristics was determined in the article.

The geometric model Su-27 SF was constructed.

During the simulation, the preliminary breakdown of the object was made on the smooth and edgel areas of the surface.

On the basis of high-frequency methods for the assessment of secondary radiation of aerodynamic district objects, results of simulation of the secondary radiation characteristics of the model of Su-27 aircraft during the probing from the bottom of the hemisphere ($3 \mathrm{deg}$ ) for the radar frequencies of the antiaircraft missileand radio troops and their analysis were carried out.

The obtained data show that the average ERAs of given model of the aircraft are in the range of $58 \ldots 83 \mathrm{~m}^{2}$, depending on the frequency of the probing signal. The histograms of the amplitude factor of the reflected signal for different frequency of radiation of the probe signal are given, they can allow to perform a number of practical tasks connected with simulation of the air environment.

The obtained results can be used at the stage of modernization of existing and designing of promising domestic radar systems in order to estimate the possibilities of various constructed variants of the systems under consideration for the identification, maintenance and recognition of air-type objects of this type.

In addition, the use of results obtained through the developed method of mathematical modeling, will optimize the design of promising domestic aircraft in order to reduce their radiolocation capacity. The developed method allows to carry out numerical simulation of radar characteristics of different type objects at given polarization, space and temporalfrequency parameters of probing signals in the interests of solving a wide range of applied radar problems.

\section{References}

1. Мартынов Н.А. Мироненко Г.Н. Оиенка характеристик рассеяния электромагнитных волн на сложных телах, частично покрытых радиопоглощзающиими материалами // Радиотехника. - 1996. - № 6. C. 102-105.

2. Юссеф Н.Н. Эффективная площадь отражения сложных радиолокационных иелей. // ТИИЭР. - 1989. T. 77, № 5. - C. 100-112.

3. Рассеяние электромагнитных волн воздушными и наземными радиолокаиионными объектами: монография / О.И. Сухаревский, В.А. Василеи, С.В. Кукобко, [и др.]; под ред. О.И. Сухаревского. - Х.: ХУПС, 2009. - 468 с., ил.

4. Ultrawideband Radar. Application and Design / edited by J.D. Taylor. - Boca Raton, London, New York: SRC Press Taylor \& Francis Group, 2012. - 520 p.

5. Electromagnetic Wave Scattering by Aerial and Ground Radar Objects / S.V. Nechitaylo, V.M. Orlenko, O.I. Sukharevsky, V.A. Vasilets; edited by O.I. Sukharevsky. Boca Raton, USA: SRC Press Taylor \& Francis Group, 2014. $334 \mathrm{p}$.

6. Scattering characteristics computation method for corner reflectors in arbitrary illumination conditions / O.I. Sukharevsky, V.A. Vasilets, S.V. Nechitaylo // International Conference on Antenna Theory and Techniques, 21-24 April, 2015, Kharkiv, Ukraine. - P. 222-224.

7. Sukhoi Su-27: [Електронний ресурс]. - Режим досmyny: https://www.britannica.com/technology/Sukhoi-Su-27.

8. Фундаментальные и прикладные задачи теории рассеяния электромагнитных волн / Ю.К. Сиренко, И.В. Сухаревский, О.И. Сухаревский, Н.П. Яшина / Под ред. Ю.К. Сиренко. - Харьков: Крок, 2000. - 344 с.

9. Характеристики розсіяння палубного винищувачабомбардувальника F/A-18A Hornet в сантиметровому, дециметровому та метровому діапазонах довжин хвиль / І.С. Ряполов, Я.О. Белевщук, Р.В. Лященко, А.В. Поляков // Наука і техніка Повітряних Сил Збройних Сил Украӥни. 2017. - № 1(26). - C. 85-91.

10. Характеристики розсіяння моделі винищувачабомбардувальника Су-17M3 в сантиметровому та 
дециметровому діапазоні довжин хвиль / I.С. Ряполов, Я.О. Белевщук, В.Ю. Колотілов, М.В. Качан, І.Р. Медінеиь // Системи озброєння і військова техніка. - 2018. - № 1(53). C. $42-48$

11. Ряполов И.Е. Высокочастотный метод расчета рассеяния вторичного излучения диэлектрических частей модели беспилотного летательного аппарата / И.Е. Ряполов, В.А. Василеи, О.И. Сухаревский // Системи обробки інформації. - 2014. - № 2(118). - C. 58-62.

12. Radar cross-section calculation for unmanned aerial vehicle / I. Ryapolov, O. Sukharevsky, V. Vasilets // Mathematical Methods in Electromagnetic Theory (MMET2014): 2014 International Conference, 26-28 August, 2014: Proceedings. - Dnepropetrovsk, 2014. - P. 258-261.
13. Beilis L.V. Radar reconnaissance capabilities estimation of low-sized low-altitude aircrafts by means of radiotechnical troops surveillance radars / L.V. Beilis, V.F. Ziukin, S.V. Kukobko // Information Processing Systems. 2017. - Vol. 1(147). - P. 6-8.

14. Шамко С.В. Основні особливості застосування Повітряних Сил в сучасних умовах ведення збройної боротьби / С.В. Шамко, О.М. Жарик, В.В. Коваль // Наука і техніка Повітряних Сил Збройних Сил Украйни. - 2017. № 2(27). - C. 15-18.

Рецензент: д.т.н., с.н.с. В.О. Василець, Харківський національний університет Повітряних Сил ім. I. Кожедуба, Харків.

\section{Оцінка характеристик вторинного випромінювання моделі багатоцільового винищувача СУ-27 в сантиметровому, дециметровому та метровому діапазонах довжин хвиль}

І.Є. Ряполов, Я.О. Белевщук, Г.М. Зубрицкий, О.В. Беспалько

У статті обтрунтована актуальність дослідження характеристик радіолокачійного розсіяння сучасних повітряних об'єктів за допомогою методів математичного моделювання. Сучасний рівень розвитку обчислювальної техніки дозволяе вирішити це завдання і реалізовувати достатньо складні методи математичного моделювання вторинного випромінювання повітряних об'єктів з необхідною точністю для використання на практиці. Проведено аналіз існуючих методів оцінювання вторинного випромінювання повітряних об'єктів, які дозволяють досягти поставленої мети - отримання характеристик радіолокаиійного розсіяння моделі багатоиільового винишувача Су-27. Ряд переваг у иьому випадку мають методи, що засновані на інтегральних уявленнях класичної електродинаміки та їх короткохвильових асимптотиках. Розроблена модель поверхні літака Су-27 та наведені основні розрахункові співвідношення, на основі яких розроблено метод чисельного моделювання. Наводяться результати розрахунку характеристик радіолокаиійного розсіяння (ефективної поверхні розсіяння, "некогерентної" ефективної поверхні розсіяння, середніх та медіанних значень ефективної поверхні розсіяння) літака Су-27 для різних частот опроміювання зондувального сигналу. Отримані результати можуть бути використані на етапі модернізації існуючих і проектування перспективних вітчизняних радіолокачійних систем з метою оцінювання можливостей різних конструктивних варіантів систем, що розглядаються, щодо виявлення, супроводження та розпізнавання повітряних об'єктів даного типу. Крім того використання результатів, які отримуються за допомогою розробленого методу математичного моделювання, дозволить оптимізувати конструкиію перспективних вітчизняних літальних апаратів з метою зменшення їх радіолокаиійної помітності. Розроблений метод дозволяс проводити чисельне моделювання радіолокаційних характеристик повітряних об'єктів різних типів при заданих поляризаціях, просторових і часовочастотних параметрах зондувальних сигналів в інтересах розв'язання широкого кола прикладних задач радіолокаиії.

Ключові слова: аеродинамічний повітряний об'єкт, вторинне випромінювання, ефективна поверхня розсіяння, метод математичного моделювання, радіолокаційні характеристики

\section{Оценка характеристик вторичного излучения модели многоцелевого истребителя СУ-27 в сантиметровом, дециметровом и метровом диапазонах длин волн}

\section{И.Е. Ряполов, Я.А. Белевщук, Г.Н. Зубрицкий, Е.В. Беспалько}

В статье обоснована актуальность исследования характеристик радиолокационного рассеивания современных воздушных объектов с помощью методов математического моделирования. Проведен анализ существующих методов оценки вторичного излучения воздушных объектов, которые позволяют достичь поставленной цели - получение характеристик радиолокационного рассеивания многоцелевого истребителя Су-27. Приводятся результать расчета характеристик радиолокационного рассеивания (эффективной поверхности рассеивания, "некогерентной" эффективной поверхности рассеивания, средних и медианных значений эффективной поверхности рассеивания) самолета Су-27 для различных частот облучения зондирующего сигнала. Полученные результаты могут быть использованы на этапе модернизации и проектирования перспективных отечественных радиолокационных систем для оиенки возможностей различных рассматриваемых конструктивных вариантов систем обнаружения, сопровождения и распознавания воздушных объектов данного типа. Кроме того, использование результатов, получаемых с помощью разработанного метода математического моделирования, позволят оптимизировать конструкиию перспективных отечественных летательных аппаратов с иелью уменьшения их радиолокационной заметности.

Ключевые слова: аэродинамический воздушный объект, вторичное излучение, эффективная поверхность рассеивания, метод математического моделирования, радиолокачионные характеристики. 